\title{
Mineral Enriched Yeast a Promising Dietary Resolution for Minerals Deficiencies
}

\author{
Mohammed Aref Kyyaly* \\ Clinical and Experimental Sciences, Southampton General Hospital, England
}

Submission: August 18, 2017; Published: September 18, 2017

*Corresponding author: Mohammed Aref Kyyaly, Faculty of medicine, Clinical and Experimental Sciences, Southampton General Hospital, University of Southampton, S016 6YD, England, Email: arefkyyaly@gmail.com

\section{Mini Review}

Humans cannot utilize most foods without critical minerals and enzymes responsible for digestion and absorption. Though mineral nutrients are essential nutrients, the body requires them in small, precise amounts. We require them in the form found in crops and they can be classified into three different categories: major, secondary, and micro or trace minerals. This classification is based upon their requirement rather than on their relative importance

Micronutrients play an important role in energy production, haemoglobin synthesis, maintenance of bone health, and protection of body against oxidative damage [1]. Mineral nutrition in humans is defined as the process by which substances in foods are transformed into body tissues and provide energy for the full range of physical and mental activities that make up human life. For example, because reversing iron deficiency anemia can require 3-6 months, it is advantageous to begin nutrition intervention before iron deficiency anemia develops [2,3].

In my previous work we provedthat ingestion of ironenriched yeast is more efficient than inorganic treatment in recovery from iron deficiency, including tissue recovery in rats [4].

Our recent studies (not published yet) showed that there was no effect of iron salt addition on the production yield when we used molasses growth medium, which is the industrial medium used for baker's yeast production, for production of iron enriched yeast. Furthermore, sensory tests of bread produced using iron enriched yeast didn't show any significant difference than the bread produced using ordinary baker's yeast.

So if mineral enriched yeast produced commercially, and used in bread and pastry products this may lead to a revolution in preventing and/or curing mineral deficiency related diseases (such as iron deficiency anemia) and also improves the life of many other diseases, like some cancers and Asthma.

Research in production of mineral enriched baker's yeast will be of high impact scientifically, commercially and on public health levels as it will be a world changing research which can treat and protect from different micronutrients deficiencies (iron, zinc, magnesium...). A lot of money can be invested to commercialize these products through either pharmaceutical industry or food industry in addition to nutrition improvement for treatment and prevention of mineral deficiencies.

\section{References}

1. Driskell J (2006) Summary: vitamins and trace elements in sports nutrition $\left(2^{\text {nd }} e d n\right)$. In: Driskell J \& Wolinsky I (Eds.), Sports nutrition. Vitamins and trace elements. CRC/Taylor \& Francis, New York, USA, pp. 323-331.

2. Lukaski HC (2004) Vitamin and mineral status: effects on physical performance. Nutrition (20): 632-644.

3. Haymes E Iron (2006) Vitamins and Trace Elements. Sports Nutrition. In: Driskell J \& Wolinsky I (Eds.), CRC/Taylor \& Francis, New York (NY) USA, pp. 203-216.

4. Kyyaly M A, Powell C, Ramadan E (2015) Preparation of iron-enriched baker's yeast and its efficiency in recovery of rats from dietary iron deficiency. Nutrition 31(9): 1155-1164. 
This work is licensed under Creative Commons Attribution 4.0 License DOI: $10.19080 / \mathrm{NFSIJ} .2017 .03 .555608$

\section{Your next submission with Juniper Publishers will reach you the below assets}

- Quality Editorial service

- Swift Peer Review

- Reprints availability

- E-prints Service

- Manuscript Podcast for convenient understanding

- Global attainment for your research

- Manuscript accessibility in different formats

( Pdf, E-pub, Full Text, Audio)

- Unceasing customer service

Track the below URL for one-step submission https://juniperpublishers.com/online-submission.php 